European Journal of

Impmuglogy

Highlights

\title{
COMMENTARY:
}

\section{Limited role for the thymus in SIV pathogenesis}

\author{
José A. M. Borghans ${ }^{1}$, Mette D. Hazenberg ${ }^{2}$ and Frank Miedema ${ }^{1}$ \\ ${ }^{1}$ Department of Immunology, University Medical Center Utrecht, Utrecht, \\ The Netherlands \\ ${ }^{2}$ Gladstone Institute of Virology and Immunology, San Francisco, USA
}

The role of the thymus in the pathogenesis of AIDS is a frequently discussed and controversial topic. Tuttleton Arron et al. studied the role of thymic output in SIV infection directly, by comparing the dynamics of TCR excision circles and CD4 ${ }^{+}$and $\mathrm{CD}^{+}{ }^{+}$cell numbers in healthy and in SIV-infected euthymic and thymectomized rhesus macaques. In this issue of the European Journal of Immunology, they report that complete abrogation of thymic output in juvenile rhesus macaques has very little impact on the peripheral T cell compartment, both in healthy and in SIV-infected macaques. Their data therefore suggest that the main cause of $\mathrm{CD}^{+}{ }^{+}$T cell loss during SIV infection is the peripheral effect of SIV, and not its effect on thymic output.
Received 13/9/04

Accepted 26/10/04

[DOI 10.1002/eji.200425643]

Key words: SIV infection

- Thymus - TREC

- Thymectomy

See accompanying article: http://dx.doi.org/10.1002/eji.200424996

\section{Thymic impairment during HIV/SIV infection}

Both HIV infection and its simian counterpart SIV infection are characterized by a progressive loss of $\mathrm{CD}^{+}$ $\mathrm{T}$ helper cells, ultimately causing susceptibility to opportunistic infections and development of AIDS. This progressive loss of $\mathrm{CD}^{+}{ }^{+} \mathrm{T}$ cells has frequently been ascribed to impairment of thymic function resulting from HIV pathology [1-3]. Indeed, several lines of evidence show that HIV is able to infect the thymus and to impair its function. Using the SCID-hu mouse model (in which human fetal liver and thymus are implanted under the kidney capsule of immunodeficient SCID mice) McCune and collaborators have shown that

Correspondence: José A. M. Borghans, Department of Immunology, KC02.085.2, Wilhelmina Children's Hospital, UMCU, Lundlaan 6, 3584 EA Utrecht, The Netherlands Fax: +31-30-2504305

e-mail: j.borghans@lab.azu.nl

Abbreviation: TREC: TCR excision circle human thymic tissue is permissive for HIV infection [4-7], leading to a decrease of the $\mathrm{CD} 4^{+}: \mathrm{CD} 8^{+}$ thymocyte ratio, and an overall reduction of thymocyte cellularity [1]. HIV-induced thymocyte loss has also been observed in fetuses aborted from HIV-infected mothers [8], in thymus biopsies from HIV-infected children $[9,10]$, in thymic tissue from individuals who died of HIV-infection who were studied at autopsy [11], and in SIV-infected rhesus macaques [12].

Yet, it remains unclear to what extent infection of the thymus contributes to the progressive $\mathrm{CD} 4^{+} \mathrm{T}$ cell loss characteristic of HIV infection. Removal of the thymus in humans generally has only a limited effect on the size of the peripheral T cell pool [13]. Even in a small group of HIV-infected individuals who were thymectomized for myasthenia gravis before they got infected with HIV, thymectomy did not preclude long-term survival. Rises in $\mathrm{CD}^{+} \mathrm{T}$ cell numbers when those thymectomized individuals were treated with highly active anti-retroviral treatment (HAART) turned out to be similar to those in non-thymectomized HIV-infected individuals 
on HAART [11]. Thus, although many data suggest that HIV and SIV interfere with thymic output, its effect on the peripheral $\mathrm{CD} 4^{+} \mathrm{T}$ cell pool may not be very large.

In this issue of the European Journal of Immunology, Tuttleton Arron et al. [14] directly studied the role of thymic output in SIV infection by infecting a group of thymectomized and a group of sham-operated juvenile rhesus macaques with SIV. Their study reveals the important insight that complete abrogation of thymic output in juvenile rhesus macaques has very little impact on the peripheral $\mathrm{T}$ cell compartment, both in healthy and in SIV-infected macaques. Their data therefore suggest that the bulk of $\mathrm{CD}^{+}{ }^{+} \mathrm{T}$ cell loss during SIV infection is due to peripheral effects of SIV, and not to thymic impairment.

\section{SIV infection and thymectomy have similar effects on the $T$ cell pool}

If thymic impairment were the dominant cause of $\mathrm{CD} 4^{+}$ T cell loss during SIV infection, removal of the thymus in healthy macaques should at least be able to induce similar changes in the peripheral CD4 ${ }^{+} \mathrm{T}$ cell pool as SIV infection does. By thymectomizing nine juvenile rhesus macaques, Tuttleton Arron et al. [14] show that lack of thymic output indeed caused a significant $\mathrm{CD} 4^{+} \mathrm{T}$ cell decline, which was comparable to the $\mathrm{CD} 4^{+} \mathrm{T}$ cell loss observed in euthymic SIV-infected macaques. Neither of these interventions had a significant impact on the number of $\mathrm{CD}^{+}{ }^{+} \mathrm{T}$ cells or naive $\mathrm{CD} 4^{+} \mathrm{T}$ cells.

To follow the influence of thymectomy on the number of recent thymic emigrants in the peripheral Tcell pool, Tuttleton Arron et al. [14] also measured TCR excision circles (TREC), the DNA by-products of TCR gene rearrangements [15]. Since TREC are extrachromosomal DNA circles, they are not copied during $\mathrm{T}$ cell division, are only produced upon de novo $\mathrm{T}$ cell generation in the thymus, and have therefore been suggested to be a good marker of thymic output. However, not only thymic output, but also T cell death and proliferation influence the average number of TREC per T cell $[16,17]$. Tuttleton Arron et al. found that both thymectomized macaques and SIV-infected macaques experienced a severe drop in TREC per $10^{6} \mathrm{CD}^{+}$and $\mathrm{CD}^{+}{ }^{+} \mathrm{T}$ cells. These decreasing TREC frequencies in SIVinfected macaques are consistent with earlier observations in HIV-infected individuals [3, 16, 18].

Taken together, Tuttleton Arron et al. thus report that thymectomy and SIV infection in juvenile rhesus macaques had similar effects on $\mathrm{CD} 4^{+} \mathrm{T}$ cell numbers and their TREC contents. At first glance, these experiments therefore seem to suggest that changes to the $\mathrm{CD} 4^{+} \mathrm{T}$ cell pool induced by SIV may in fact be caused by the deleterious effects of SIV on the thymus.

\section{SIV infection affects the CD $4^{+} \mathrm{T}$ cell pool of thymectomized and sham-thymectomized macaques equally}

If the main effect of SIV infection would indeed be a significant reduction of thymic output, one would expect that infection of thymectomized macaques with SIV would not severely worsen their situation. However, Tuttleton Arron et al. found that in thymectomized macaques, SIV infection also led to a significant loss of CD4 ${ }^{+} \mathrm{T}$ cells and TREC per $10^{6} \mathrm{CD} 4^{+} \mathrm{T}$ cells. In fact, the major decline of $\mathrm{CD} 4^{+} \mathrm{T}$ cells and their TREC contents was seen upon SIV infection, whereas thymectomy alone had only minor effects. Additionally, the loss of $\mathrm{CD} 4^{+} \mathrm{T}$ cells and total TREC numbers in the $\mathrm{CD}^{+}{ }^{+} \mathrm{T}$ cell population of thymectomized, SIV-infected macaques was not significantly faster than in sham-operated, SIVinfected animals. Together, these observations demonstrate that the main loss of TREC and $\mathrm{CD} 4^{+} \mathrm{T}$ cells that is characteristic of SIV infection is not due to SIV-induced thymic impairment but to other, peripheral effects of SIV.

The data also confirm our previous claim that the average numbers of TREC per $10^{6} \mathrm{CD}^{+}$or $\mathrm{CD}^{+} \mathrm{T}$ cells are more strongly influenced by $\mathrm{T}$ cell division than by thymic dysfunction, and that they can therefore not be taken to reflect thymic function [16]. Although SIV may interfere with thymic output, the effect of impaired thymic function is thus not the dominant factor causing the progressive decline of CD4 $4^{+}$T cells and TREC per $10^{6}$ $\mathrm{CD}^{+} \mathrm{T}$ cells during infection.

Even if reduced thymic output is not the major cause of $\mathrm{CD}^{+}{ }^{+} \mathrm{T}$ cell decline during SIV infection, it is of interest to know whether the presence of functional thymic tissue could at least have beneficial effects. The fact that SIV-infected euthymic and thymectomized macaques experienced a similar $\mathrm{CD}^{+} \mathrm{T}$ cell decline seems to suggest that the presence of thymic tissue makes no difference. However, one cannot exclude the possibility that SIV has such a strong deleterious effect on the thymus that by comparing sham-operated, SIVinfected macaques with thymectomized, SIV-infected macaques one in fact just compares two cases of SIVinfected macaques without thymic function. The study of Tuttleton Arron et al. suggests that this is not the case, by providing data from thymectomized healthy juvenile macaques; these data suggest that the contribution of thymic output to the maintenance of the peripheral $\mathrm{CD}^{+} \mathrm{T}$ cell pool is anyway limited. 


\section{Limited contribution of the thymus to maintenance of the peripheral $\mathrm{T}$ cell pool in healthy macaques}

By following the absolute numbers of TREC of noninfected thymectomized macaques over time, the authors elegantly estimated the decay rate of TRECbearing cells and thereby the fraction of cells entering the peripheral pool from the thymus per day. Thymic output was found to be small: only $0.2-0.3 \%$ of the peripheral T cell pool had migrated from the thymus per day, which is equivalent to an absolute thymic output of about $2-3 \times 10^{8} \mathrm{~T}$ cells per day. Using more indirect approaches, thymic output in human adults has also been estimated to be low, in the order of $10^{8} \mathrm{~T}$ cells per day [19]. Because of this, naive $\mathrm{T}$ cell reconstitution is very slow following $\mathrm{T}$ cell depletion caused by various situations such as chemotherapy, conditioning for bonemarrow/stem-cell transplantation, monoclonal antibody treatment or HIV infection [20-23]. In addition, it explains why thymectomy affects peripheral blood $\mathrm{T}$ cell numbers and TREC levels only to a minor extent in HIV-negative human adults [13] and juvenile macaques [14].

Since thymic output in juvenile macaques and in human adults is so small, even complete abrogation of thymic output by SIV would not be expected to significantly affect the size of the peripheral $\mathrm{T}$ cell pool. However, this hypothesis had yet to be proven, as there are to date no direct experimental approaches to actually quantitate thymic function in vivo. The data obtained by Tuttleton Arron et al. are unique in that for the first time a direct method is used that shows that the contribution of the thymus to maintenance of the $\mathrm{T}$ cell pool and to SIV-pathogenesis is limited.

\section{Relevance to pediatric HIV-infection}

Importantly, since thymic output is known to decline progressively with age, and the macaque study was performed in juveniles, an even smaller contribution of thymic output would be expected in adult macaques or adult humans. We have recently tested the hypothesis that in young children - in whom thymic function is considered to be optimal - HIV infection of the thymus may have a significant contribution to HIV-induced $\mathrm{CD}^{+}{ }^{+} \mathrm{T}$ cell loss. To this end, we followed changes in total body $\mathrm{CD} 4^{+} \mathrm{T}$ cell numbers and total $\mathrm{CD} 4^{+}$TREC numbers with age in a group of healthy children of different ages.

If the major source of $\mathrm{CD} 4^{+} \mathrm{T}$ cells in young children were the thymus, one would expect the dynamics of $\mathrm{CD}^{+} \mathrm{T}$ cell and TREC numbers to be very similar. Instead we found large discrepancies between the two.
While total body naive $\mathrm{CD} 4^{+} \mathrm{T}$ cell numbers increased during the first years of life, total CD4 ${ }^{+}$TREC numbers remained stable during this period, suggesting that the increase in naive $\mathrm{T}$ cell numbers was largely due to peripheral T cell proliferation [24]. Thus, even in young healthy children, thymic output seems to be less critical in maintaining or increasing peripheral blood naive $\mathrm{T}$ cell numbers than previously thought, and HIV-related impairment of thymic function may therefore not have a significant impact on peripheral blood $\mathrm{T}$ cell numbers. The data presented by Tuttleton Arron et al. are compatible with these observations.

\section{Concluding remarks}

Taken together, the study of Tuttleton Arron et al. provides some new and exciting insights about normal T cell homeostasis, and about SIV pathogenesis. Thymectomy in healthy juvenile macaques had only a mild effect on $\mathrm{CD} 4^{+} \mathrm{T}$ cell and TREC dynamics. Of note, the authors suggest that these changes induced a compensatory increase in peripheral $\mathrm{T}$ cell proliferation. However, whereas thymectomy only affected the $\mathrm{CD}^{+}{ }^{+} \mathrm{T}$ cell decline, Ki67 expression was up-regulated in both $\mathrm{CD}^{+}$ and $\mathrm{CD}^{+} \mathrm{T}$ cells, and only months after surgery. Increased Ki67 expression could therefore also be related to antigen-exposure, and the effects of thymectomy on homeostatic changes in $\mathrm{T}$ cell proliferation and $\mathrm{T}$ cell lifespan, if any, still need to be addressed.

Importantly, the authors showed that the thymus does not play a central role in SIV-induced $\mathrm{CD} 4^{+} \mathrm{T}$ cell decline. Indeed other, peripheral mechanisms have been suggested to play a more crucial role in SIV- and HIVpathogenesis; one such mechanism is chronic immune activation, which has been proposed to cause erosion of the naive Tcell pool and thereby depletion of $\mathrm{CD} 4^{+} \mathrm{T}$ cell numbers [25-28].

Acknowledgements: This work was financially supported by AIDS Fonds Netherlands (7011), the Netherlands Organization for Scientific Research (NWO, 916.36.003) and the European Molecular Biology Organization (EMBO) ALTF 254-2002.

\section{References}

1 Bonyhadi, M. L., Rabin, L., Salimi, S., Brown, D. A., Kosek, J., McCune, J. M. and Kaneshima, H., HIV induces thymus depletion in vivo. Nature 1993. 363: $728-732$.

2 McCune, J. M., The dynamics of $\mathrm{CD}^{+}{ }^{+}$T-cell depletion in HIV disease. Nature 2001. 410: 974-979.

3 Douek, D. C., McFarland, R. D., Keiser, P. H., Gage, E. A., Massey, J. M., Haynes, B. F., Polis, M. A., Haase, A. T., Feinberg, M. B., Sullivan, J. L., et al., Changes in thymic function with age and during the treatment of HIV infection. Nature 1998. 396: 690-695. 
4 McCune, J. M., Namikawa, R., Kaneshima, H., Shultz, L. D., Lieberman, M. and Weissman, I. L., The SCID-hu mouse: Murine model for the analysis of human hematolymphoid differentiation and function. Science 1988. 241: 1632-1639.

5 McCune, J., Kaneshima, H., Krowka, J., Namikawa, R., Outzen, H., Peault, B., Rabin, L., Shih, C. C., Yee, E., Lieberman, M. et al., The SCIDhu mouse: a small animal model for HIV infection and pathogenesis. Annu. Rev. Immunol. 1991. 9: 399-429.

6 Namikawa, R., Kaneshima, H., Lieberman, M., Weissman, I. L. and McCune, J. M., Infection of the SCID-hu mouse by HIV-1. Science 1988. 242: 1684-1686.

7 Namikawa, R., Weilbaecher, K. N., Kaneshima, H., Yee, E. J. and McCune, J. M., Long-term human hematopoiesis in the SCID-hu mouse. J. Exp. Med. 1990. 172: 1055-1063.

8 Papiernik, M., Brossard, Y., Mulliez, N., Roume, J., Brechot, C., Barin, F., Goudeau, A., Bach, J. F., Griscelli, C., Henrion, R. and Vazeux, R., Thymic abnormalities in fetuses aborted from human immunodeficiency virus type 1 seropositive women. Pediatrics 1992. 89: 297-301.

9 Joshi, V. V., Oleske, J. M., Saad, S., Gadol, C., Connor, E., Bobila, R. and Minnefor, A. B., Thymus biopsy in children with acquired immunodeficiency syndrome. Arch. Path. Lab. Med. 1986. 110: 837-842.

10 Rosenzweig, M., Clark, D. P. and Gaulton, G. N., Selective thymocyte depletion in neonatal HIV-1 infection. AIDS 1993. 7: 1601-1605.

11 Haynes, B. F., Hale, L. P., Weinhold, K. J., Patel, D. D., Liao, H.-X., Bressler, P. B., Jones, D. M., Demarest, J. F., Gebhard-Mitchell, K., Haase, A. T. and Bartlett, J. A., Analysis of the adult thymus in reconstitution of T lymphocytes in HIV-1 infection. J. Clin. Invest. 1999. 103: 453-460.

12 Baskin, G. B., Murphey-Corb, M., Martin, L. N., Davison-Fairburn, B., Hu, F. S. and Kuebler, D., Thymus in simian immunodeficiency virus-infected rhesus monkeys. Lab. Invest. 1991. 65: 400-407.

13 Sempowski, G. D., Thomasch, J. R., Gooding, M. E., Hale, L. P., Edwards, L. J., Ciafaloni, E., Sanders, D. B., Massey, J. M., Douek, D. C., Koup, R. A. and Haynes, B. F., Effect of thymectomy on human peripheral blood T cell pools in myasthenia gravis. J. Immunol. 2001. 166: 2808-2817.

14 Tuttleton Arron, S., Ribeiro, R. M., Gettie, A., Bohm, R., Blanchard, J., Yu, J., Perelson, A. S., Ho, D. D. and Zhang, L., Impact of thymectomy on the peripheral T cell pool in rhesus macaques before and after infection with simian immunodeficiency virus. Eur. J. Immunol. 2005. 35: this issue.

15 Kong, F.-K., Chen, C.-L. H., Six, A., Hockett, R. D. and Cooper, M. D., Tcell receptor gene deletion circles identify recent thymic emigrants in the peripheral T cell pool. Proc. Natl. Acad. Sci. USA 1999. 96: 1536-1540.

16 Hazenberg, M. D., Otto, S. A., Cohen Stuart, J. W. T., Verschuren, M. C. M., Borleffs, J. C. C., Boucher, C. A. B., Coutinho, R. A., Lange, J. M. A., Rinke de Wit, T. F., Tsegaye, A. et al., Increased cell division but not thymic dysfunction rapidly affects the TREC content of the naive T cell population in HIV-1 infection. Nat. Med. 2000. 6: 1036-1042.
17 Hazenberg, M. D., Verschuren, M. C. M., Hamann, D., Miedema, F. and Van Dongen, J. J. M., T cell receptor excision circles as markers for recent thymic emigrants: basic aspects, technical approach, and guidelines for interpretation. J. Mol. Med. 2001. 79: 631-640.

18 Zhang, L., Lewin, S. R., Markowitz, M., Lin, H.-H., Skulsky, E., Karanicolas, R., He, Y., Jin, X., Tuttleton, S., Vesanen, M. et al., Measuring recent thymic emigrants in blood of normal and HIV-1-infected individuals before and after effective therapy. J. Exp. Med. 1999. 190: 725-732.

19 Clark, D. R., De Boer, R. J., Wolthers, K. C. and Miedema, F., T cell dynamics in HIV-1 infection. Adv. Immunol. 1999. 73: 301-327.

20 Rep, M., Van Oosten, B. W., Roos, M. T. L., Adèr, H. J., Polman, C. H. and Van Lier, R., Treatment with depleting CD4 monoclonal antibody results in a preferential loss of circulating naive $\mathrm{T}$ cells but does not affect IFN- $\gamma$ secreting TH1 cells in humans. J. Clin. Invest. 1997. 99: 2225-2231.

21 Mackall, C. L., Fleisher, T. A., Brown, M., Andrich, M. P., Chen, C., Feuerstein, I. M., Horowitz, M. E., Magrath, I. T., Shad, A. T., Steinberg, S. M. et al., Age, thymopoiesis, and $\mathrm{CD}^{+}{ }^{+} \mathrm{T}$-lymphocyte regeneration after intensive chemotherapy. N. Engl. J. Med. 1995. 332: 143-149.

22 Fujimaki, K., Maruta, A., Yoshida, M., Kodama, F., Matsuzaki, M., Fujisawa, S., Kanamori, H. and Ishigatsubo, Y., Immune reconstitution assessed during five years after allogeneic bone marrow transplantation. Bone Marrow Transplant. 2001. 27: 1275-1281.

23 Roux, E., Dumont-Girard, F., Starobinski, M., Siegrist, C. A., Helg, C., Chapuis, B. and Roosnek, E., Recovery of immune reactivity after T cell depleted bone marrow transplantation depends on thymic activity. Blood 2000. 96: 2299-2303.

24 Hazenberg, M. D., Otto, S. A., Van Rossum, A. M., Scherpbier, H. J., De Groot, R., Kuijpers, T. W., Lange, J. M., Hamann, D., De Boer, R. J., Borghans, J. A. M. and Miedema, F., Establishment of the $\mathrm{CD}^{+}{ }^{+} \mathrm{T}$ cell pool in healthy and untreated HIV-1 infected children. Blood 2004.. 12: 3513-3519.

25 Silvestri, G., Sodora, D. L., Koup, R. A., Paiardini, M., O'Neil, S. P., McClure, H. M., Staprans, S. I. and Feinberg, M. B., Nonpathogenic SIV infection of sooty mangabeys is characterized by limited bystander immunopathology despite chronic high-level viremia. Immunity 2003. 18: $441-452$.

26 Grossman, Z., Meier-Schellersheim, M., Sousa, A. E., Victorino, R. M. M. and Paul, W. E., CD4 T-cell depletion in HIV infection: are we closer to understanding the cause? Nat. Med. 2002. 8: 319-323.

27 Hazenberg, M. D., Hamann, D., Schuitemaker, H. and Miedema, F., T cell depletion in HIV-1 infection: how CD4 ${ }^{+}$T cells go out of stock. Nat. Immunol. 2000. 1: 285-289.

28 Hazenberg, M. D., Otto, S. A., van Benthem, B. H., Roos, M. T., Coutinho, R. A., Lange, J. M., Hamann, D., Prins, M. and Miedema, F., Persistent immune activation in HIV-1 infection is associated with progression to AIDS. AIDS 2003. 17: 1881-1888. 